\title{
LESZEK ĆWIKŁA*
}

\author{
PRAWNE ASPEKTY ROZWOJU TURYSTYKI \\ PIELGRZYMKOWEJ W POLSCE W LATACH 1918-1939
}

\section{Streszczenie}

W Drugiej Rzeczypospolitej ważnym zjawiskiem religijnym, kulturowym oraz społeczno-ekonomicznym była - tak jak i dzisiaj - turystyka pielgrzymkowa. Zamierzeniem autora artykułu było dokonanie analizy przepisów prawa obowiązujących w tym okresie oraz udzielenie odpowiedzi na pytanie, czy ustawodawstwo państwowe miało pozytywny wpływ na rozwój tego rodzaju turystyki. Podstawowymi aktami normatywnymi, których przepisy zostały poddane analizie, są Konstytucja Marcowa z 1921 r. oraz Konstytucja Kwietniowa z 1935 r. Przepisy ustaw zasadniczych gwarantowały obywatelom m.in. wolność kultu, zaś związkom wyznaniowym, uznanym przez państwo, prawo do urządzania zbiorowych i publicznych nabożeństw. W zakresie ustawodawstwa zwykłego przeanalizowano przepisy kodeksu karnego z 1932 r., ustawy o zgromadzeniach z 1932 r. oraz przepisy odnoszące się do czasu wolnego od pracy (ustanawiające dni wolne od pracy oraz wprowadzające instytucję urlopu wypoczynkowego). Zwrócono też uwagę na projekt „ustawy turystycznej”, który zawierał regulacje mogące mieć wpływ na rozwój turystyki pielgrzymkowej. W dalszej kolejności przeanalizowano akty prawne wydane przez ministra komunikacji, przewidujące ulgi dla pielgrzymów podróżujących koleją, a także akty prawne wydane przez inne organy, zawierające przepisy obowiązujące pielgrzymów wyjeżdżających za granicę lub przyjeżdżających z zagranicy do Polski. Przeprowadzona analiza przepisów prawa pozwoliła na stwierdzenie, że działania władz państwowych, uznających doniosłą rolę religii w funkcjonowaniu państwa i społeczeństwa, sprzyjały rozwojowi turystyki

* Dr hab., prof. KUL, Katedra Negocjacji i Mediacji, Wydział Prawa, Prawa Kanonicznego i Administracji, Katolicki Uniwersytet Lubelski Jana Pawła II, Al. Racławickie 14, 20-950 Lublin, e-mail: leszek.cwikla@kul.pl. ORCID 0000-0002-4048-6653. 
pielgrzymkowej. Przepisy nie przewidywały ograniczeń i uprawianie tego rodzaju turystyki mogło odbywać się swobodnie.

Słowa kluczowe: turystyka; pielgrzymki; turystyka pielgrzymkowa; Konstytucja Marcowa; konstytucja RP z 1921 r.; przepisy wyznaniowe; wolność kultu; wolność sumienia i religii

$* * * * *$

\section{WPROWADZENIE}

Turystyka pielgrzymkowa, zwana pątniczą lub pielgrzymowaniem, jest jedną z najstarszych i stale rozwijających się form turystyki religijnej ${ }^{1}$. Jej istotą jest odwiedzanie miejsc kultu religijnego w kraju lub za granicą w celu spełnienia aktów religijnych, pokuty i pobożności. Często wiąże się z udziałem w uroczystościach religijnych w miejscu kultu². Może mieć charakter indywidualny lub zorganizowany.

Początki turystyki pielgrzymkowej sięgają starożytności i związane są z wędrówkami do miejsc uważanych za święte, czyli do miejsc, gdzie znajdowały się wyrocznie lub świątynie, w których oddawano cześć bóstwom. Tego typu wędrówki opisane są na kartach Ksiąg Starego i Nowego Testamentu. Niewątpliwie pielgrzymem był Jezus Chrystus, a także apostołowie (szczególnie św. Paweł z Tarsu) ${ }^{3}$. Pielgrzymki cieszyły się szczególną popu-

1 W przypadku turystyki pielgrzymkowej na plan pierwszy zostaje wysunięty wyraźnie określony motyw religijny. Gdy podczas podróży lub wędrówki do miejsca świętego jego uczestnik zredukuje doświadczenie religijne, mamy do czynienia z turystyką religijną, ale nie pielgrzymkową. Z kolei jeśli podróżowanie do miejsc (obiektów) sakralnych pozbawione zostanie jakiejkolwiek motywacji religijnej, wówczas możemy mówić o turystyce kulturalnej, którą mogą uprawiać również ludzie niewierzący. Zob. Jackowski 1998, 5-20; Michałowski 2003, 181; Różycki 2016, 15; Potocki 2007, 217-219; Jackowski 2003, 123; Ostrowski 1996, 354.

Jackowski 1998, 11.

3 Łazarek, Łazarek 2005, 9-36; Różycki 2016, 42-44. 
larnością w okresie średniowiecza ${ }^{4}$. W rozwoju średniowiecznej turystyki kluczową rolę odegrał Kościół, starający się zapewnić pielgrzymom daleko idącą opiekę i ochronę. Głosząc hasło tzw. „Pokoju Bożego” (łac. Treuga Dei), które zawierało zakaz dokonywania napadów i prowadzenia walk od środy wieczorem do poniedziałku rano, Kościół przyczynił się do zapewnienia podróżującym bezpieczeństwa. Przepisy prawne odnoszące się do podróżowania i pielgrzymowania znalazły się w poszczególnych zbiorach tworzących kodyfikację prawa kanonicznego Kościoła rzymskokatolickiego - Corpus Iuris Canonici ${ }^{5}$. Do świętych miejsc pielgrzymowali również muzułmanie oraz poganie na wszystkich kontynentach ${ }^{6}$. Podróże pielgrzymkowe były popularne także w następnych epokach ${ }^{7}$.

W Polsce tradycja pielgrzymowania sięga początków istnienia państwa polskiego i przyjęcia chrześcijaństwa. Do grobu św. Wojciecha, ogłoszonego jako męczennika za wiarę, przybywali pielgrzymi nawet spoza państwa polskiego. Miejscami pielgrzymkowymi stały się Poznań i Kraków. Od roku 1382, tzn. od momentu, gdy książę opolski Władysław przywiózł do Polski słynący cudami obraz Matki Bożej z dzieciątkiem, zaczęły się pielgrzymki na Jasną Górę. Już w średniowieczu ustalił się zwyczaj organizowania pielgrzymek do Świętej Lipki ${ }^{8}$.

Pielgrzymki do miejsc kultu religijnego cieszyły się dużą popularnością również w Polsce w okresie międzywojennym. Propagował je przede wszystkim Kościół Katolicki i w związku z tym zajmowały one szczególne miejsce w jego działalności duszpasterskiej, służąc realizacji w szerokich kręgach społeczeństwa zadań w dziedzinie kultowej, moralnej i społeczno-wychowawczej. Rozwojowi turystyki pielgrzymkowej sprzyjały działania władz państwowych, które uznawały doniosłą rolę religii w funkcjonowaniu państwa i społeczeństwa. Szczególnie działalność Kościoła Katolickiego była uznawana za zgodną z interesem państwa oraz dobrem jego oby-

4 W okresie średniowiecza za rodzaj pielgrzymki uznawano wyprawy krzyżowe. Ponadto szeroko rozwijał się ruch pielgrzymkowy do miejsc kultu znanych z objawień lub relikwii, a także miały miejsce pielgrzymki odpustowe. Zob. Różycki 2016, 45-63; Michałek 2004, 13; Mruk 1996, 113-124; Łazarek, Łazarek 2005, 74-77; Strzelczyk 2004.

Szerzej na ten temat zob. Uruszczak 2018, 549-558.

6 Szerzej na ten temat zob. Łazarek, Łazarek 2005, 110-140; Ohler 2000.

7 Szerzej na ten temat zob. Różycki 2016, 64-70.

8 Łazarek, Łazarek 2005, 112. 
wateli i była popierana9 ${ }^{9}$ W przypadku turystyki pielgrzymkowej zwracano uwagę na jej cele edukacyjne oraz wpływ na kształtowanie odpowiednich postaw patriotycznych i prospołecznych.

W latach trzydziestych XX w. władze państwowe postanowiły wykorzystać możliwości, jakie stwarzała turystyka w zakresie polepszenia katastrofalnej sytuacji, będącej skutkiem światowego kryzysu gospodarczego, który nastąpił po słynnym krachu w 1929 r. Pielgrzymki zaczęto traktować jako jedną z form turystyki masowej. $\mathrm{Z}$ ich inicjatywy zostało utworzone w kwietniu 1935 r. stowarzyszenie - Liga Popierania Turystyki, które zajęło się m.in. popularyzacją turystyki pielgrzymkowej ${ }^{10}$. Liga ściśle współpracowała z przedsiębiorstwem państwowym Polskie Koleje Państwowe, gdyż z uwagi na ówczesne możliwości najlepszym sposobem przemieszczania się była podróż koleją.

Zamierzeniem autora artykułu jest dokonanie analizy przepisów prawa obowiązujących w Drugiej Rzeczypospolitej oraz udzielenie odpowiedzi na pytanie, czy ustawodawstwo państwowe miało wpływ na rozwój turystyki pielgrzymkowej. W związku z tak postawionym celem postępowania badawczego hipoteza badawcza brzmi: przepisy prawa ułatwiały rozwój ruchu pielgrzymkowego i nie wprowadzały w tym zakresie istotniejszych ograniczeń.

9 Piekarski 1927, 95-96.

10 Stowarzyszenie - zgodnie z przepisem art. 21 rozporządzenia Prezydenta Rzeczypospolitej z dnia 27 października 1932 r. Prawo o stowarzyszeniach, Dz. U. z 1932 r. $\mathrm{Nr}$ 94, poz. 808 - zostało wpisane do rejestru stowarzyszeń i związków Komisariatu Rządu m. st. Warszawy pod numerem 640 na podstawie decyzji Komisarza Rządu m. st. Warszawy z dnia 13 kwietnia 1935 r. Nr BSII-3/679. Zob. Statut Ligi Popierania Turystyki. 1935, 16. [br. m. wyd.]. Wśród założycieli Ligi byli: K. Świtalski - marszałek Sejmu, W. Raczkiewiczmarszałek Senatu, S. Starzyński - prezydent Warszawy, M. Grażyński - wojewoda śląski, H. Gruber - prezes PKO, H. Szatkowski - naczelnik Wydziału Turystyki Ogólnej Ministerstwa Komunikacji oraz liczni generałowie Wojska Polskiego. Prezesem zarządu został były premier J. Jędrzejewicz. 


\section{REGULACJE KONSTYTUCYJNE I USTAWOWE}

Przyjęta przez Sejm Rzeczypospolitej Polskiej w 1921 r. Konstytucja Marcowa ${ }^{11}$ zagwarantowała wolność religijną poszczególnym obywatelom lub mieszkańcom państwa oraz daleko idącą swobodę pracy duszpasterskiej związkom wyznaniowym. Osobista, indywidualna wolność religijna obywateli obejmowała wolność sumienia, wolność wyznania oraz wolność kultu (art. 111 ust. 1 Konstytucji). Z kolei wszystkim mieszkańcom Rzeczypospolitej zostało przyznane prawo wolnego wyznawania zarówno publicznie, jak i prywatnie swej wiary (art. 111 ust. 2 Konstytucji). Związki wyznaniowe (określone terminem ,związki religijne”) uznane przez państwo miały zagwarantowane prawo do urządzania zbiorowych i publicznych nabożeństw (art. 113 Konstytucji). Artykuły 111-113 zostały utrzymane w niezmienionej postaci w Konstytucji Kwietniowej ${ }^{12}$. W przypadku Kościoła Katolickiego zasada ,pełnej wolności” została dodatkowo potwierdzona w art. 1 konkordatu zawartego ze Stolicą Apostolską w dniu 10 lutego 1925 r. $^{13}$

Ustawodawca w odrodzonym państwie polskim, uznając wolność kultu, nie wskazał - tak samo jak i obecnie - czym jest ,kult”. Według przedstawicieli ówczesnej doktryny wolność kultu wyrażała się m.in. w prawie do uzewnętrzniania swojej wiary oraz wykonywania praktyk religijnych ${ }^{14}$. Oznacza to, że każdy miał prawo do uczestniczenia w pielgrzymkach, a władza państwowa nie mogła stawiać przeszkód ani tym bardziej z tego powodu dyskryminować. Natomiast użyte w art. 113 Konstytucji pojęcie

11 Konstytucja Rzeczypospolitej Polskiej z dnia 17 marca 1921 r., Dz. U. z 1921 r. Nr 44, poz. 267.

12 Stanowi o tym art. 81 ust. 2 ustawy konstytucyjnej z dnia 23 kwietnia 1935 r., Dz. U. z 1935 r. Nr 30, poz. 227.

13 Ustawa z dnia 23 kwietnia 1925 r. o zatwierdzeniu układu ze Stolicą Apostolską, określającego stosunek Państwa do Kościoła Rzymsko-Katolickiego, Dz. U. z 1925 r. Nr 47, poz. 324.

14 Komarnicki 1922, 574. Zob. też Łysko 2013, 67-69. Współcześnie pojęcie kultu religijnego jest definiowane jako ogół zewnętrznych działań podejmowanych przez człowieka religijnego służących bezpośrednio wyrażeniu jego czci dla przedmiotu jego wiary (Boga, Absolutu, bóstwa, bóstw, świętych postaci, świętych przedmiotów, innych upostaciowień sacrum, innych obiektów wiary religijnej). Zob. Mezglewski 2011, 223-227. 
nabożeństwa, zdaniem doktryny, było nie do końca właściwe, a wynikało prawdopodobnie $\mathrm{z}$ niedokładnego tłumaczenia odpowiedniego przepisu konstytucji austriackiej, na której w zakresie przepisów wyznaniowych ustawodawca polski się wzorował. W istocie dozwolone były ,wszystkie czynności religijne". Stanowisko takie wynika z faktu, iż skoro Konstytucja $\mathrm{w}$ art. 111 ust. 2 pozwalała każdemu mieszkańcowi na publiczne wykonywanie obrządku swej religii, to nielogiczne byłoby ograniczenie związków wyznaniowych uznanych przez państwo w swobodzie publicznego wykonywania kultu religijnego ${ }^{15}$. Z brzmienia art. 113 wynika, że prawa do publicznego wykonywania kultu religijnego nie miały związki prawnie nieuznane. Oznacza to, że jednostki organizacyjne takich związków nie mogły publicznie sprawować kultu polegającego na organizowaniu pielgrzymek. Był to jeden z przejawów braku zasady równouprawnienia związków wyznaniowych. Pielgrzymka członków takiej wspólnoty mogła mieć jedynie charakter prywatnej uroczystości kultowej, chociaż zgodnie z art. 111 ust. 2 mieli oni prawo do publicznego wyznawania swej wiary. Niewątpliwie świadczy to o wewnętrznej niekonsekwencji przepisów konstytucji.

Kult publiczny związku wyznaniowego o uregulowanej sytuacji prawnej podlegał ochronie prawnokarnej. Rozdział XXVI w Kodeksie karnym z 15 lipca 1932 r. $^{16}$, zatytułowany „Przestępstwa przeciw uczuciom religijnym" zawierał trzy artykuły przewidujące sankcje za przestępstwa przeciwko wolności religijnej. Z punktu widzenia rozważanego zagadnienia najistotniejsze znaczenie miał art. 174, przewidujący karę aresztu do lat 2 dla sprawcy, który złośliwie przeszkadzał publicznemu, zbiorowemu wykonywaniu aktu religijnego. Zgodnie z tym przepisem przestępcze działanie musiało być wymierzone w ,akt religijny”, a więc w każdą czynność o charakterze religijnym ${ }^{17}$.

Jako że pielgrzymka jest formą zgromadzenia publicznego, dla rozwoju tego rodzaju turystyki istotne znaczenie miały również przepisy traktujące o zgromadzeniach publicznych. Prawo zgromadzeń publicznych gwarantował obywatelom art. 108 Konstytucji Marcowej, zaś wy-

\footnotetext{
15 Abraham 1922, 126-127.

16 Dz. U. z 1932 r. Nr 60, poz. 571.

17 Peiper 1933, 491.
} 
konanie tego prawa miały określać ustawy. Ponieważ przez 14 lat, a więc do dnia wejścia w życie ustawy z dnia 11 marca 1932 r. o zgromadzeniach $^{18}$, została uchwalona tylko jedna ustawa ${ }^{19}$, kwestie zgromadzeń regulowane były przez ustawodawstwo byłych państw zaborczych. Zgromadzeń dotyczyły: rosyjskie tymczasowe przepisy o zgromadzeniach z dnia 4/17 marca 1906 r. ${ }^{20}$, rozporządzenie Komisarza Generalnego Ziem Wschodnich z dnia 25 maja 1919 r. o zgromadzeniach ${ }^{21}$, austriacka ustawa $\mathrm{z}$ dnia 15 listopada $1867 \mathrm{r}^{22}$ oraz niemiecka ustawa o stowarzyszeniach z dnia 19 kwietnia 1908 r. ${ }^{23}$ Ustawodawstwo pozaborcze wyłączyło pielgrzymki w celach religijnych spod zakresu obowiązywania ustawodawstwa dotyczącego zgromadzeń ${ }^{24}$. Jeżeli chodzi o ustawę o zgromadzeniach z dnia 11 marca 1932 r., to według art. 27 ust. 1 lit. b jej przepisy nie miały zastosowania do pochodów urządzanych przez związki religijne prawnie uznane, o ile odbywały się ,w sposób tradycyjnie ustalony lub przewidziany w akcie, uznającym dane wyznanie oraz do pochodów we-

18 Dz. U. z 1932 r. Nr 48, poz. 450.

19 Chodzi o ustawę z dnia 5 sierpnia 1922 r. w sprawie wolności zgromadzeń przedwyborczych, Dz. U. z 1922 r. Nr 66, poz. 594.

20 Tymczasowe przepisy o zgromadzeniach z dnia 4/17 marca 1906 r. (dodatek do art. $115^{1}$ ustawy o uprzedzeniu i zapobieżeniu przestępstw) zawarte w t. XIV Zwodu praw Cesarstwa Rosyjskiego, w: Makowski 1913, 53-65 (tekst również w: Zbiór ważniejszych ustaw i rozporządzeń administracyjnych (ogólnych i dzielnicowych) obowiąujacych w Rzeczypospolitej Polskiej. 1925. Oprac. Stanisław Czaputowicz, Tadeusz Sikorski, 143-145. Warszawa: Skład główny Księgarnia F. Hoesicka, Księgarnia św. Wojciecha).

21 Dz. Urz. Zarządu Cywilnego Ziem Wschodnich z 1919 r. Nr 5, poz. 30.

22 Ustawa z dnia 15 listopada 1867 o prawie zgromadzania się, w: Kodeks prawa politycznego czyli Austryackie Ustawy Konstytucyjne 1848-1903. 1903. Przekł. i oprac. Stanisław Starzyński, 749-763. Lwów: K. S. Jakubowski. Tekst ustawy również w: Zbiór ważniejszych ustaw... 1925, 126-132. Ustawa w języku niemieckim w: „Reichs-Gesetz-Blatt für das Kaiserthum Österreich" 1867 , poz. 135, s. 382-384.

23 Ustawa z dnia 19 kwietnia 1908 r., w: Nowe prawo o stowarzyszeniach i zebraniach z dnia 19-go kwietnia 1908 roku jako té przepisy wykonawcze, mianowicie pruskie z dnia 8-go maja 1908 roku w niemieckim i polskim języku z objaśnieniami i wzorami podań do władz (zgłoszeń, zażaleń $i$ t. d.). 1908. Oprac. Konstanty Kościński, 5-23. Poznań: nakład autora (tekst ustawy również w: Zbiór ważniejszych ustaw... 1925, 128-132).

24 Zob. art. 22 tymczasowych przepisów o zgromadzeniach z dnia 4/17 marca 1906 r.; $\S 5$ ustawy z dnia 15 listopada 1867 o prawie zgromadzania się; § 24 niemieckiej ustawy o stowarzyszeniach z dnia 19 kwietnia 1908 r. 
selnych i pogrzebowych". W przepisie tym nie zostały wymienione pielgrzymki, co powodowało pewne wątpliwości interpretacyjne odnośnie do tego, czy w przypadku publicznego sprawowania kultu polegającego na organizacji pielgrzymki konieczne jest dokonanie zawiadomienia lub uzyskanie zezwolenia właściwego organu administracyjnego. Przedstawiciele doktryny wskazywali, że art. 27 ust. 1 lit. b należy stosować również do pielgrzymek ${ }^{25}$. Ostatecznie wątpliwości rozwiał Sąd Najwyższy w wyroku z dnia 6 grudnia 1937 r. (III K 1331/37), stwierdzając, że przepisy ustawy nie mają zastosowania również do pielgrzymek ${ }^{26}$. Artykułem 27 ust. 2 ustawy ustawodawca dopuścił możliwość podjęcia niezbędnych działań, gdyby zgromadzenie o charakterze religijnym (a więc i pielgrzymka) mogło zagrażać bezpieczeństwu, spokojowi lub porządkowi publicznemu. $\mathrm{W}$ takim przypadku właściwy organ władzy miał prawo wydania odpowiedniego zarządzenia.

Analizując ustawodawstwo, które miało wpływ na rozwój turystyki pielgrzymkowej, warto zwrócić uwagę na regulacje prawne odnoszące się do czasu wolnego od pracy, a więc przede wszystkim ustanawiające dni wolne od pracy oraz wprowadzające instytucję urlopu wypoczynkowego. Oczywiście zasadniczym celem dni wolnych od pracy jest zapewnienie pracownikowi stosownego odpoczynku, który jest niezbędny do prawidłowej pracy, ale pracownik wierzący ma możliwość wypełnienia w tym czasie praktyk religijnych.

W Polsce międzywojennej obowiązywał ośmiogodzinny dzień pracy (od poniedziałku do piątku). W sobotę wymiar czasu pracy miał wynosić sześć godzin, zaś w przypadku handlu sześciogodzinny dzień pracy mógł być przeniesiony na mocy uchwały rady gminnej z dnia sobotniego na inny dzień powszedni, przy czym uchwała taka wymagała zatwierdzenia Ministra Pracy i Opieki Społecznej. Ośmio- lub sześciogodzinny wymiar czasu pracy nie musiał być zachowany, jeśli charakter zajęć wymagał dłuższej jednorazowej pracy, z tym że ogólna liczba godzin pracy w tygodniu nie mogła przekraczać 46 godzin. W 1933 r. czas pracy w sobotę wydłużono do 8 godzin. Praca w niedzielę i święta była dozwolona tylko w przy-

25 Ustawa o zgromadzeniach. 1932. Oprac. Maurycy Richter, 35. Przemyśl: Wydawnictwo Książnicy Naukowej.

26 Zob. Orzecznictwo Sądu Najwyższego. Izba Karna z 1938 r. Nr 6, poz. 148. 
padkach określonych prawem ${ }^{27}$. Dniami wolnymi od pracy były - oprócz wszystkich niedziel - następujące dni świąteczne: Nowy Rok (1 stycznia), Trzech Króli (6 stycznia), Oczyszczenie Najświętszej Maryi Panny (2 lutego), drugi dzień Wielkanocy, Trzeci Maja, Wniebowstąpienie Pańskie, drugi dzień Zesłania Ducha Świętego, Boże Ciało, Świętych Apostołów Piotra i Pawła (29 czerwca), Wniebowzięcie Najświętszej Maryi Panny (15 sierpnia), Wszystkich Świętych (1 listopada), Niepokalane Poczęcie Najświętszej Maryi Panny (8 grudnia), Boże Narodzenie (25 grudnia), drugi dzień Bożego Narodzenia (26 grudnia) ${ }^{28}$. Należy zauważyć, iż katalog świąt wymienionych w rozporządzeniu Prezydenta Rzeczypospolitej i w ustawie zawiera tylko święta katolickie. W ustawodawstwie międzywojennym brak było odpowiednika art. 42 ust. 1 obecnie obowiązującej ustawy z dnia z 17 maja 1989 r. o gwarancjach wolności sumienia i wyznania ${ }^{29}$, zgodnie z którym osoby należące do kościołów i innych związków wyznaniowych, których święta religijne nie są dniami ustawowo wolnymi od pracy, mogą na własną prośbę uzyskać zwolnienie od pracy lub nauki na czas niezbędny do obchodzenia tych świąt, zgodnie z wymogami wyznawanej przez siebie religii. Brak takiej regulacji powodował, że niekatolicy, którzy stanowili znaczny odsetek obywateli państwa, mieli nieco ograniczone możliwości wypełniania praktyk religijnych.

Instytucję urlopu wypoczynkowego ustawodawca uregulował w kilku aktach normatywnych ${ }^{30}$. Długość urlopu została uzależniona od ro-

27 Zob. art. 1-3 dekretu [z dnia 23 listopada 1918 r.] o 8-mio godzinnym dniu pracy, Dz.P.P.P. z 1918 r. Nr 17, poz. 42 oraz Dz. Urz. Min. Spraw Wew. z 1918 r. Nr 3, poz. 32 oraz Dz. Urz. Min. Kom. z 1919 r. Nr 1, poz. 2 oraz Dz. Urz. Min. Rol. i Dóbr Pań. z 1919 r. Nr 2, s. 3-4. Zob. też art. 1 i 11 ustawy z dnia 18 grudnia 1919 r. o czasie pracy w przemyśle i handlu, Dz. U. z 1920 r. Nr 2, poz. 7 oraz art. 1 pkt 1 ustawy z dnia 22 marca 1933 r. w sprawie zmian w ustawie z dnia 18 grudnia 1919 r. o czasie pracy w przemyśle i handlu, Dz. U. z 1933 r. Nr 27, poz. 227 oraz M.P. z 1933 r. Nr 94, dział urzędowy.

28 Paragraf 1 rozporządzenia Prezydenta Rzeczypospolitej z dnia 15 listopada 1924 r. o dniach świątecznych, Dz. U. z 1924 r. Nr 101, poz. 928 oraz art. 1 ustawy z dnia 18 marca 1925 r. w przedmiocie zmiany rozporządzenia Prezydenta Rzeczypospolitej z dnia 15 listopada 1924 r. o dniach świątecznych, Dz. U. z 1925 r. Nr 34, poz. 234.

29 Tekst jedn. Dz. U. z 2017 r. poz. 1153.

30 Zob. ustawęz dnia 16 maja 1922 r. o urlopach dla pracowników, zatrudnionych w przemyśle i handlu, Dz. U. z 1922 r. Nr 40, poz. 334 (wbrew tytułowi objęła zakresem podmiotowym nie tylko pracowników przedsiębiorstw przemysłowych i handlowych, ale wszystkich 
dzaju pracy i stażu pracy. W lepszej sytuacji znajdowali się pracownicy umysłowi, którzy w porównaniu z pracownikami fizycznymi nabywali prawo do pierwszego urlopu wypoczynkowego po okresie krótszego stażu pracy oraz przysługiwał im urlop wypoczynkowy w większym wymiarze $^{31}$. Dodatkowo warto wskazać, że w Polsce prawne uregulowanie

zakładów pracy, państwowych i samorządowych); ustawę z dnia 17 lutego 1922 r. o państwowej służbie cywilnej, Dz. U. z 1922 r. Nr 21, poz. 164 (uregulowała uprawnienia urlopowe funkcjonariuszy państwowej służby cywilnej z wyłączeniem sędziów i prokuratorów, nauczycieli i wykładowców wyższych uczelni oraz pracowników kolei i poczty; niektóre przepisy ustawy do wyjścia w życie ustaw szczegółowych były stosowane wobec funkcjonariuszy policji, straży celnej, służby więziennej i pracowników monopoli państwowych); ustawę z dnia 1 lipca 1926 r. o stosunkach służbowych nauczycieli, Dz. U. z 1926 r. Nr 92, poz. 530; rozporządzenie Prezydenta Rzeczypospolitej z dnia 24 lutego 1928 r. o stosunku służbowym profesorów państwowych szkół akademickich i pomocniczych sił naukowych tych szkół, Dz. U. z 1928 r. Nr 24, poz. 204 z późn. zm.; tymczasową instrukcję ogólną dla sądów Królestwa Polskiego z dnia 21 sierpnia 1917 r., Dz. Urz. Departamentu Sprawiedliwości Tymczasowej Rady Stanu z 1917 r. Nr 2, dział III, poz. 4; rozporządzenie Prezydenta Rzeczypospolitej z dnia 6 lutego 1928 r. Prawo o ustroju sądów powszechnych, Dz. U. z 1928 r. Nr 12, poz. 93. Szerzej na temat instytucji urlopu wypoczynkowego w II Rzeczypospolitej zob. Ćwikła 2015, 61-91.

31 Przykładowo, robotnik po nieprzerwanym roku pracy uzyskiwał 8 dni płatnego urlopu, a po trzech latach - $15 \mathrm{dni}$, pracownik umysłowy po sześciu miesiącach pracy nabywał prawo do 14-dniowego urlopu, zaś po roku pracy - do miesięcznego. Pracownikom młodocianym, poniżej 18. roku życia, terminatorom (czyli uczniom pobierającym naukę rzemiosła pod okiem mistrza; po zakończeniu nauki uzyskiwali oni tytuł czeladnika) oraz uczniom przysługiwało prawo do 14-dniowego urlopu po roku nieprzerwanej pracy (w dwóch ostatnich przypadkach również jeżeli byli zatrudnieni w zakładzie zatrudniającym do czterech pracowników). Funkcjonariusze państwowej służby cywilnej mieli prawo do czterotygodniowego urlopu wypoczynkowego, jeśli ich staż pracy wynosił do dziesięciu lat, do pięciotygodniowego urlopu, jeśli ich staż pracy wynosił od dziesięciu do dwudziestu lat oraz do sześciotygodniowego urlopu przy stażu pracy ponad dwadzieścia lat. Funkcjonariusze niżsi mieli prawo do dwutygodniowego urlopu, jeśli przepracowali do dziesięciu lat, do trzytygodniowego urlopu, jeśli przepracowali od dziesięciu do dwudziestu lat oraz do czterotygodniowego urlopu, jeśli przepracowali ponad dwadzieścia lat. Nauczyciele (oprócz nauczycieli szkół wyższych) mieli prawo do urlopu wypoczynkowego w takim samym wymiarze jak funkcjonariusze państwowej służby cywilnej. Urlop wypoczynkowy profesorów szkół akademickich był uregulowany w sposób bardzo ogólny - ustawodawca wskazał bowiem jedynie, że mieli oni prawo do takiego urlopu w okresie ferii. Z kolei niesamodzielni pracownicy naukowi uczelni, zwani w okresie międzywojennym ,pomocniczymi siłami naukowymi”, mieli prawo do urlopu wypoczynkowego w okresie 
instytucji urlopu wypoczynkowego nastąpiło wcześniej niż w większości państw Europy.

Na początku lat trzydziestych XX w. władze państwowe podjęły prace nad „ustawą turystyczną”. Jej projekt przygotowało Ministerstwo Robót Publicznych i następnie był on procedowany w ramach Międzyministerialnej Komisji Turystycznej, utworzonej uchwałą Komitetu Ekonomicznego Rady Ministrów w dniu 28 marca 1931 r. ${ }^{32}$ Projekt zawierał przepisy mające istotne znaczenie z punktu widzenia turystyki pielgrzymkowej. Tak więc miejscowości, w których znajdowały się ,,przedmioty kultu religijnego", miały uzyskać status miejscowości turystycznych w ścisłym znaczeniu (według projektu miejscowości turystyczne miały być podzielone na trzy grupy - uzdrowiska, miejscowości wypoczynkowe oraz miejscowości turystyczne w ścisłym znaczeniu). Miejscowości o takim statusie miały być wspierane środkami finansowymi pochodzącymi m.in. z opłat obowiązkowych, które miały być nakładane na podmioty prowadzące działalność w branży turystycznej oraz na turystów przybywających do danej miejscowości ${ }^{33}$. Niestety prace nad ustawą przeciągały się m.in. z powodu

wakacyjnym w wymiarze od czterech do sześciu tygodni. Termin urlopu ustalał profesor. Sędziom przysługiwał urlop sześciotygodniowy (w byłym zaborze austriackim sędziom sądów powiatowych i okręgowych przysługiwał urlop czterotygodniowy), wymiar urlopu urzędników kancelarii mógł wynosić maksymalnie cztery tygodnie, wymiar urlopu woźnych sądowych wynosił 14 dni. Od 1 stycznia 1929 r. sędzia grodzki miał prawo do pięciotygodniowego wypoczynku w każdym roku kalendarzowym (od 3 lutego 1930 r. tylko ten, którego staż pracy wynosił do dziesięciu lat), inni zaś sędziowie - prawo do sześciotygodniowego wypoczynku. Analogiczne przepisy obowiązywały w stosunku do prokuratorów: podprokurator okręgowy miał prawo do pięciotygodniowego wypoczynku w każdym roku, inni zaś prokuratorzy - do sześciotygodniowego.

32 Zob. pismo Ministra Robót Publicznych N. Neugebauera do Ministra Spraw Wewnętrznych z dnia 9 kwietnia 1931 r., Archiwum Akt Nowych (dalej: AAN), Ministerstwo Spraw Wewnętrznych w Warszawie. Sprawy różne 1923-1931, sygn. 753, k. 3-4; „Działalność referatu turystyki Min. Rob. Publ. w r. 1931”. 1932. Wierchy. Rocznik poświęcony górom i góralszczyźnie 10: 182; Sprawozdanie z konferencji Międzymin. Komisji Turystycznej odbytej w dniu 21/V b.r. w Ministerstwie Robót Publicznych w sprawie rozwoju turystyki, AAN, Ministerstwo Spraw Wewnętrznych w Warszawie. Sprawy różne 1923-1931, sygn. 753, k. 80-83. Szerzej zob. Ćwikła 2011, 82-83, 311-317.

33 Zob. założenia do projektu ustawy o popieraniu turystyki, AAN, Ministerstwo Spraw Wewnętrznych w Warszawie. Sprawy różne 1923-1931, sygn. 753, k. 101-108. Zob. także „Projekt ustawy o popieraniu turystyki. Praca krakowskiej Izby Przemysłowo-Handlowej”. 
reorganizacji administracji centralnej, która miała miejsce w 1932 r., oraz braku zgody zainteresowanych podmiotów odnośnie do poszczególnych rozwiązań. W rezultacie projekt został skierowany ad acta.

\section{REGULACJE ZAWARTE W AKTACH PODUSTAWOWYCH}

Dla rozwoju turystyki pielgrzymkowej istotne znaczenie miały regulacje zawarte w aktach prawnych wydanych przez Ministra Komunikacji ${ }^{34}$. W 1934 r. zostały wprowadzone bilety ulgowe dla pielgrzymów udających się na Jasną Górę. W ten sposób chciano zachęcić społeczeństwo do korzystania $\mathrm{z}$ transportu kolejowego ${ }^{35}$. Ulga przysługiwała $\mathrm{w}$ ciągu całego roku i obowiązywała w przypadku podróży pociągami osobowymi lub pospiesznymi w I, II lub III klasie na odległość nie mniejszą niż $30 \mathrm{~km}$. Grupa pielgrzymów musiała liczyć przynajmniej 25 osób. Dodatkowo na 50 osób płacących jedna osoba w charakterze przewodnika mogła podróżować bezpłatnie, z tym że osób takich mogło być nie więcej niż trzy.

W 1937 r. została zorganizowana akcja „PKP - Najmilszym Turystom", której celem było umożliwienie przewiezienia przez osobę dorosłą, posiadającą normalny lub ulgowy bilet kolejowy, pięciorga dzieci w wieku do 14 lat, płacąc za nie jedną ósmą część taryfy normalnej ${ }^{36}$. Zniżka ob-

Turystyka. Biuletyn Polskiego Biura Podróży »Orbis« z 1 kwietnia 1934 r., nr 6: 2-3; „Prace Izb Przemysłowo-Handlowych nad ustawą turystyczną”. Turystyka. Biuletyn Polskiego Biura Podróży »Orbis« z 15 maja 1934 r., nr 9: 4; „Projekt ustawy o miejscowościach wypoczynkowych i turystycznych". Ilustrowany Kuryer Codzienny z 26 kwietnia 1935 r., nr 114: 21-22; Fularski 1935, 107.

34 Minister Komunikacji w okresie dwudziestolecia międzywojennego zarządzał kolejami państwowymi jako przedsiębiorstwem państwowym. Co prawda w 1926 r. zostało utworzone przedsiębiorstwo Polskie Koleje Państwowe jako samoistna osoba prawna, jednak do wybuchu drugiej wojny światowej nie zostało ono wydzielone $\mathrm{z}$ administracji państwowej (osoba prawna nie otrzymała odrębnych organów, więc nie może być uważana za istniejącą). Zob. Ćwikła 2011, 204-206.

35 Zob. § 1 obwieszczenia w sprawie ulg przejazdowych, stosowanych na linjach normalnotorowych Polskich Kolei Państwowych, wydanych na mocy rozporządzenia Ministra Komunikacji w zakresie uprawnień do udzielania ulg pozataryfowych, Dziennik Taryf i Zarządzeń Kolejowych z 1934 r. Nr 1, dział II.

36 M.P. z 1937 r. Nr 158, dział nieurzędowy. 
jęła również grupowe wyjazdy pielgrzymów do Częstochowy, Kalwarii Zebrzydowskiej, Wilna i do innych miejscowości o znaczeniu pątniczym oraz zorganizowane grupy, liczące ponad 15 osób, udające się na uroczystości odpustowe, pod warunkiem że w miejscowości była stacja kolejowa.

Oprócz zniżek zostały wprowadzone inne udogodnienia, mające znaczenie dla rozwoju turystyki pielgrzymkowej. Biura podróży, komitety oraz osoby zajmujące się organizacją pielgrzymek mogły rezerwować miejsca w wagonach pasażerskich, prosić o wyznaczenie oddzielnego wagonu lub uruchomienie pociągu dodatkowego. Kwestie te zostały uregulowane przez Ministra Komunikacji w rozporządzeniu z dnia 14 września 1931 r. $^{37}$ Zgodnie $\mathrm{z}$ treścią rozporządzenia miejsca $\mathrm{w}$ pociągach lub wagonach mogły być zapewnione w miarę możności dla pielgrzymki liczącej co najmniej 25 osób, zgłoszonej najpóźniej na dwa dni przed zamierzonym wyjazdem. Równocześnie ze zgłoszeniem zamawiający miejsca obowiązany był złożyć na stacji wyjazdu kaucję, której wysokość uzależniona była od klasy przedziału i od odległości pomiędzy stacją wyjazdu a stacją docelową lub graniczną, wynoszącą od 3 do 5 zł od osoby. W przypadku mniejszej liczby osób wyjeżdżających niż zgłoszonych część kaucji odpowiadająca liczbie osób brakujących przepadała na rzecz kolei. Na podobnych zasadach odbywała się rezerwacja oddzielnych wagonów i pociągów dodatkowych; opłatę za przejazd pobierano za rzeczywistą liczbę jadących osób, przy czym ogólna należność nie mogła być niższa od z góry określonej stawki, uzależnionej od rodzaju wagonu, jego klasy i od tego, czy podróżni korzystali ze zniżek czy nie. Jeśli wartość biletów nie odpowiadała najniższej z góry określonej opłacie, należało pobrać od osób korzystających z wagonu odpowiednią dopłatę (pkt 1-9). Zgodnie z pkt $10 \mathrm{w}$ przypadku przejazdu oddzielnych wagonów przez więcej niż jeden kolejowy okręg dyrekcyjny fakt ten należało uzgodnić z wszystkimi zainteresowanymi dyrekcjami. Ponadto nie można było rezerwować oddzielnych wagonów na wyjazd za granicę. Wyjątkowo Ministerstwo Komunikacji mogło udzielić

37 Rozporządzenie Ministra Komunikacji z dnia 14 września 1931 r. Nr. IV/2/5769/31 o zapewnieniu miejsc w pociągach pasażerskich i wyznaczaniu oddzielnych wagonów dla wycieczek, pielgrzymek, transportów emigrantów, robotników i t.p. oraz uruchamianiu pociągów dodatkowych, Dz. Urz. Min. Kom. z 1931 r. Nr 19, poz. 146 oraz Dziennik Taryf i Zarządzeń Kolejowych z 1931 r. Nr 33, poz. 412. 
zgody na wyodrębnienie oddzielnego wagonu dla udających się za granicę pielgrzymek okrężnych (pkt 11).

Inną inicjatywą, która sprzyjała rozwojowi m.in. turystyki pielgrzymkowej, było uruchomienie przez PKP tzw. pociągów popularnych. Miały one ułatwić przejazd do miejscowości, w których miały miejsce obchody i uroczystości. W dniu 14 lutego 1933 r. Minister Komunikacji wydał stosowne zarządzenie. Dotyczyło ono ustalenia wymaganego minimum frekwencji pociągu popularnego - 300 osób (wówczas cena biletów była obliczana ze zniżką 66\%). Jeśli w pielgrzymce brało udział co najmniej 350 osób - zniżka wynosiła 70\%. W dniu 17 stycznia 1934 r. ukazało się rozporządzenie Ministra Komunikacji (R.P. IV/77/276) w sprawie: „Przepisów o pociągach popularnych"38. Pociągi popularne mogły organizować dyrekcje okręgowe kolei państwowych lub mogły je zamawiać w dyrekcjach biura podróży, towarzystwa turystyczne, krajoznawcze lub inne organizacje i instytucje o charakterze społecznym. Zgodę na uruchomienie pociągu wydawało Ministerstwo Komunikacji. Wniosek o uruchomienie pociągu popularnego należało złożyć przynajmniej na 14 dni przed wyjazdem. Wraz z wnioskiem należało złożyć kaucję, która według uznania dyrekcji wynosiła od 100 do 500 zł. W przypadku odmowy ze strony Ministerstwa Komunikacji kaucja była zwracana, natomiast odwołanie zamówionego pociągu powodowało jej przepadek w całości na rzecz kolei. Opłatę pobierano przy wyjeździe za przejazd w obie strony, za całą trasę pociągu popularnego, bez względu na to, na jakiej stacji uczestnik wycieczki wsiądzie lub wysiądzie. Opłata najniższa za przejazd pociągiem popularnym wynosiła 70\% zniżki przy liczbie minimum 400 uczestników. Do przejazdu pociągami popularnymi nie uprawniały - co do zasady - żadne bilety bezpłatne lub ulgowe. Jedynie właściwa dyrekcja mogła według własnego uznania udzielić bezpłatnych biletów w liczbie nieprzekraczającej $1 \%$ sprzedanych biletów, licząc całe setki. Ewentualnie dyrekcje mogły na polecenie Gabinetu Ministra zwolnić z opłaty przedstawicieli radia i prasy, w zamian za bezpłatne ogłaszanie komunikatów, reklam i sprawozdań o pociągach popularnych.

Od czerwca 1935 r. pociągi popularne mogły być uruchamiane dla wycieczek organizowanych z inicjatywy dyrekcji okręgowych kolei pań-

38 Dz. Urz. Min. Kom. z 1934 r. Nr 3, poz. 11. 
stwowych, czyli tzw. pociągi popularne dyrekcyjne lub z inicjatywy Ligi Popierania Turystyki w porozumieniu $\mathrm{z}$ organizacjami turystycznymi, krajoznawczymi, instytucjami i organizacjami sportowymi, kulturalno-oświatowymi, społecznymi, komitetami obchodów, zjazdów, wystaw i targów - tzw. pociągi popularne na zamówienie. Celem wycieczek w pociągach popularnych miało być m.in. umożliwienie wzięcia udziału ludności w uroczystościach religijnych. Minimum uczestniczących w wycieczce w pociągu popularnym było określone na 200 osób. Instytucje i organizacje były zobowiązane do zgłaszania wniosków o uruchomienie pociągu popularnego do delegatury Ligi Popierania Turystyki przy dyrekcjach okręgowych kolei państwowych, które następnie przekazywały je do Ministerstwa Komunikacji. Pociąg popularny mógł być uruchomiony jedynie po uzyskaniu zezwolenia Ministerstwa Komunikacji ${ }^{39}$.

Można postawić pytanie: ilu pielgrzymów skorzystało z przejazdów tzw. pociągami popularnymi? Według danych Ligi Popierania Turystyki pociągami takimi do Częstochowy w 1935 r. przybyło ponad 92 tys. osób, zaś w 1936 r. - 236,5 tys. osób, w 1936 r. do Kalwarii Zebrzydowskiej przybyło 17 tys. osób, do Gniezna 10 tys., a do Piekar Śląskich 8 tys. ${ }^{40}$ Na marginesie można dodać, że w 1933 r. kolej uruchomiła 397 pociągów popularnych, w 1934 r. - 394, w 1935 r. - 589, w 1936 r. - 972. W pociągach popularnych przewieziono: w 1934 r. - 250 tys. osób, w 1935 r. - 413 tys., w 1936 r. -646 tys., w 1937 r. -297 tys. oraz w 1938 r. -805 tys. ${ }^{41}$

Władze państwowe starały się propagować przede wszystkim krajowe wyjazdy pielgrzymkowe, co znalazło swój wyraz również w przepisach prawnych. Zgodnie z okólnikiem Ministerstwa Skarbu z dnia 14 października $1931 \mathrm{r}^{42}$ osoby pragnące uczestniczyć w piel-

39 Fularski 1935, 62-63; Szczepański 1935, 6.

40 Dwa lata Ligi Popierania Turystyki. Sprawozdanie z działalności Ligi Popierania Turystyki za okres od 15 czerwca 1935 do 30 października. 1937, 40. Warszawa: Zarząd Główny Ligi Popierania Turystyki.

41 Faecher 1937, 21-46; Bobkowski 1955, 5-6.

42 Okólnik Ministerstwa Skarbu z dnia 14 października 1931 r. (D.V. 17868/1/31) w sprawie interpretacji $\S 4$ pkt 1 e) rozporządzenia Ministra Skarbu w porozumieniu z Ministrem Spraw Wewnętrznych z dnia 20 czerwca 1931 r., Dz. U. z 1931 r. Nr 56, poz. 460. Okólnik został dołączony w formie załącznika do okólnika [Ministerstwa Spraw Wewnętrznych] Nr. 189 z dnia 4 listopada 1931 r. (AP. 5409/2) w sprawie interpretacji przepisów 
grzymce zagranicznej mogły otrzymać paszport ulgowy lub bezpłatny, ale warunkiem było przedłożenie zaświadczenia z Ministerstwa Skarbu, które stanowiło podstawę do wystawienia takiego paszportu. Ministerstwo zalecało ograniczenie do minimum wyjazdów za granicę na podstawie paszportów ulgowych, uzasadniając to trudną sytuacją gospodarczą państwa i koniecznością przeciwdziałania odpływowi środków pieniężnych za granicę. W związku z tym zostały określone normy dochodu lub majątku, które stanowiły maksymalne granice, powyżej których osoby ubiegające się o ulgowe paszporty w celu wyjazdu za granicę należało traktować jako zamożne ${ }^{43}$. Rozwiązanie to $\mathrm{w}$ znacznym stopniu utrudniało wyjazdy zagraniczne, ponieważ wówczas na tego typu podróże mogli sobie pozwolić jedynie ludzie bogaci. Ponadto osoby wyjeżdżające za granicę miały bardzo ograniczone możliwości wywozu zagranicznych środków płatniczych w formie akredytyw (czeków) ${ }^{44}$.

Starano się też zachęcać cudzoziemców do przyjazdu do Polski. Przykładowo, uczestnicy pielgrzymki zorganizowanej mogli uzyskać

rozporządzenia z 20.VI.1931 r. o opłatach za paszporty zagraniczne, Dz. Urz. Min. Spraw Wew. z 1931 r. Nr 19, poz. 298.

43 Zob. AAN, Ministerstwo Wyznań Religijnych i Oświecenia Publicznego w Warszawie, Zbiór okólników i zarządzeń normatywnych w układzie tematycznym 1937, sygn. 26, k. 164. Zob. też pismo podsekretarza stanu w Ministerstwie WRiOP z dnia 13 listopada 1931 r. do kuratoriów okręgów szkolnych, Śląskiego Urzędu Wojewódzkiego Wydziału Oświaty Publicznej, Liceum Krzemienieckiego, szkół akademickich oraz Państwowego Instytutu Dentystycznego w Warszawie, informujące o zaprzestaniu wydawania przez Ministerstwo Skarbu zezwoleń na zwolnienie od normalnych opłat za paszporty zagraniczne dla uczestników zbiorowych wycieczek turystycznych, oraz okólnik Ministerstwa Wyznań Religijnych i Oświecenia Publicznego Nr 73 z dnia 19 maja 1932 r. (I Org-4060/32) w sprawie ograniczenia wydawania ulgowych paszportów zagranicznych, AAN, Ministerstwo Wyznań Religijnych i Oświecenia Publicznego w Warszawie, Zbiór okólników i zarządzeń normatywnych w układzie tematycznym 1932, sygn. 24, k. 239; pismo podsekretarza stanu w Ministerstwie WRiOP z dnia 13 listopada 1931 r. do kuratoriów okręgów szkolnych, Śląskiego Urzędu Wojewódzkiego Wydziału Oświaty Publicznej, Liceum Krzemienieckiego, szkół akademickich oraz Państwowego Instytutu Dentystycznego w Warszawie, informujące o zaprzestaniu wydawania przez Ministerstwo Skarbu zezwoleń na zwolnienie od normalnych opłat za paszporty zagraniczne dla uczestników zbiorowych wycieczek turystycznych, AAN, Ministerstwo Wyznań Religijnych i Oświecenia Publicznego w Warszawie, Zbiór okólników i zarządzeń normatywnych w układzie tematycznym 1937, sygn. 26, k. 164.

44 Zob. Ćwikła 2011, 350-369. 
wizy wjazdowe bezpłatne, pod warunkiem iż przybyli drogą powietrzną z wykorzystaniem samolotów przewożących mniej niż dziesięciu pasażerów ${ }^{45}$. Ponadto obowiązek meldunkowy takiej grupy miał być realizowany w trybie uproszczonym poprzez doręczenie właściwym organom władzy listy uczestników pielgrzymki, a nie indywidualnych kart meldunkowych. Kwestie te regulowało rozporządzenie Ministra Spraw Wewnętrznych wydane w porozumieniu z innymi ministrami z dnia 16 października $1930 \mathrm{r}^{46}$ W myśl § 19 rozporządzenia dodatkowymi warunkami były: a) wymóg, by pielgrzymka przybyła z kierownikiem, posiadającym zaświadczenie wydane przez właściwe władze lub instytucje, stwierdzające charakter pielgrzymki i fakt jej zorganizowania pod przewodnictwem danej osoby (zaświadczenie nie było wymagane w przypadku pielgrzymki przybywającej z zagranicy na podstawie polskiej wizy zbiorowej), b) posiadanie przez kierownika podpisanej przez siebie listy uczestników pielgrzymki, jeśli wymóg taki został zastrzeżony w zaświadczeniu, c) w zastępstwie uczestników pielgrzymki jej kierownik dokonywał zawiadomienia o przybyciu lub wyjeździe oraz udzielał informacji niezbędnych do zameldowania lub wymeldowania, d) obowiązkowi zameldowania i wymeldowania podlegał tylko kierownik pielgrzymki, zaś jeśli chodzi o pozostałych uczestników pielgrzymki, to kierownik zobowiązany był do przekazania organom gminy listy uczestników lub ewentualnie liczby uczestników pielgrzymki, wskazania czasu (liczba dni), w jakim pielgrzymka ma przebywać w danej miejscowości, podania swojego imienia, nazwiska i adresu oraz wskazania miejscowości, z której pielgrzymka wyruszyła ${ }^{47}$.

Natomiast turysta z zagranicy, który przybył w celach pielgrzymkowych indywidualnie, zobowiązany był do wypełnienia karty meldunko-

45 Instrukcja o wycieczkach zbiorowych krajowych i zagranicznych, pkt I: Wycieczki zbiorowe cudzoziemców do Polski, Dz. Urz. Min. Spraw Zag. z 1934 r. Nr 5, poz. 24.

46 Dz. U. z 1930 r. Nr 84, poz. 653. Obowiązek meldunkowy, któremu podlegali wszyscy cudzoziemcy, został nałożony art. 8 rozporządzenia Prezydenta Rzeczypospolitej z dnia 13 sierpnia 1926 r. o cudzoziemcach, Dz. U. z 1926 r. Nr 83, poz. 465. Zgodnie $\mathrm{z}$ art. 8 ust. 1 pierwszego z wymienionych rozporządzeń obowiązek meldunkowy winien być dopełniany w ciągu dwudziestu czterech godzin od chwili przybycia.

47 Rozporządzenie zostało zastąpione rozporządzeniem Ministra Spraw Wewnętrznych z dnia 23 maja 1934 r. o meldunkach i księgach ludności, Dz. U. z 1934 r. Nr 54, poz. 489. Brzmienie $\S 19$ nie uległo zmianie. 
wej w miejscu każdorazowego zatrzymania się na nocleg (np. w hotelu, w pensjonacie). Kierownik obiektu musiał w ciągu 24 godzin od chwili przybycia turysty zameldować go w gminie, bez względu na czas, przez który przebywał lub zamierzał przebywać (art. 5 i 7 ust. 2 rozporządzenia Prezydenta Rzeczypospolitej z dnia 16 marca 1928 r. o ewidencji i kontroli ruchu ludności $\left.{ }^{48}\right)$.

\section{PODSUMOWANIE}

Turystyka pielgrzymkowa w Drugiej Rzeczypospolitej była - tak jak i dzisiaj - ważnym zjawiskiem religijnym, kulturowym oraz społeczno-ekonomicznym. W latach dwudziestych rozwijała się słabo, co było spowodowane trudnościami, z jakimi musiało borykać się społeczeństwo po odzyskaniu niepodległości, w tym z ograniczonymi możliwościami finansowymi. Natomiast w latach trzydziestych sytuacja uległa poprawie.

Turystyka pielgrzymkowa, będąc wyrazem religijności społeczeństwa i gwarantowanej prawem wolności kultu, nie podlegała kontroli ze strony państwa. Władze państwowe, doceniając znaczenie pierwiastka religijnego dla funkcjonowania państwa i społeczeństwa, wykazywały przychylny stosunek do kościołów i innych związków wyznaniowych oraz prowadzonej przez nie działalności, zaś osobom wierzącym starały się ułatwiać zaspokajanie ich duchowych potrzeb. Znajdowało to wyraz przede wszystkim w stanowionych przepisach prawnych. Na podstawie przeprowadzonego postępowania badawczego należy stwierdzić, iż obowiązujące wówczas przepisy prawa sprzyjały rozwojowi turystyki pielgrzymkowej. Nieliczne ograniczenia były konieczne dla zapewnienia bezpieczeństwa oraz porządku publicznego, nie można ich więc uznać za ograniczanie wolności kultu. Wolności kultu nie naruszały również przepisy wprowadzające ulgi na przejazdy kolejowe. Co prawda ulgi dotyczyły przejazdów do miejsc pielgrzymkowych związanych z Kościołem Katolickim, ale było to spowodowane brakiem możliwości dojazdu koleją do miejsc pielgrzymkowych innych kościołów lub związków wyznaniowych. W ten sposób została potwierdzona sformułowana we wprowadzeniu hipoteza badawcza.

48 Dz. U. z 1928 r. Nr 32, poz. 309. 
Warto zwrócić uwagę, iż część przepisów prawnych odnosiła się wyłącznie do turystyki pielgrzymkowej połączonej z podróżą. Wśród tych przepisów brak było jednak regulacji zapewniających ochronę interesów pielgrzymów uczestniczących w wyjazdach. W przypadku pieszych pielgrzymek, nawet jeśli trasa przebiegała drogami publicznymi, nie było wymogu uzgadniania ich z organami władzy państwowej. Oczywiście pielgrzymi nie stanowili wyjątku, gdyż w okresie dwudziestolecia międzywojennego w ogóle brak było przepisów prawnych chroniących interesy turystów. Ponieważ piesze pielgrzymki w ówczesnych realiach nie stanowiły większego zagrożenia dla bezpieczeństwa ruchu drogowego, ich organizacja nie była uregulowana prawnie.

Wypada też zauważyć, iż w okresie dwudziestolecia międzywojennego związki wyznaniowe w niewielkim stopniu angażowały się w organizowanie wyjazdów związanych m.in. z odwiedzaniem miejsc świętych, a tym bardziej nie prowadziły działalności turystyczno-pielgrzymkowej, jak to ma miejsce obecnie ${ }^{49}$. Bardzo często wyjazdy takie organizowały różnego rodzaje stowarzyszenia prowadzące działalność w dziedzinie turystyki. Niektóre z nich miały to nawet zapisane w statutach. Przykładem takiego stowarzyszenia może być utworzony w 1926 r. Polski Klub Turystyczny ${ }^{50}$. Jego celem - jak stanowił $§ 7$ statutu - było, ,rozwijanie, popieranie i ułatwianie turyzmu w najszerszym zakresie i we wszystkich jego formach”, popularyzacja turystyki i krajoznawstwa oraz organizowanie wypraw o charakterze naukowym i turystycznym. Realizacja celu miała nastąpić m.in. poprzez organizację wycieczek i pielgrzymek krajowych i zagranicznych.

\section{BIBLIOGRAFIA}

Abraham, Władysław. 1922. „Konstytucja a stosunki wyznaniowe i Kościół”. W: Nasza konstytucja. Cykl odczytów urządzonych staraniem Dyrekcji Szkoty

49 Na temat działalności turystyczno-pielgrzymkowej prowadzonej przez związki wyznaniowe zob. Tunia 2014, 239-252.

50 Polski Klub Turystyczny został wpisany do rejestru stowarzyszeń i związków pod nr 1534 na podstawie postanowienia Ministerstwa Spraw Wewnętrznych z dnia 2 kwietnia 1926 r. Nr BB. 2859/26, Dz. Urz. Min. Spraw Wew. z 1926 r. Nr 4, poz. 331; Polski Klub Turystyczny. Statut. 1927: 3. Warszawa. 
Nauk Politycznych w Krakowie od 12-25 maja 1921 r., 112-134. Kraków: nakład autorów.

Bobkowski, Aleksander. 1955. Turystyka w niepodległej Polsce. Ze wspomnień A. Bobkowskiego. Genewa: [b. w.].

Ćwikła, Leszek. 2011. Prawne aspekty rozwoju turystyki $w$ Polsce $w$ latach 1918-1939. Lublin: Wydawnictwo KUL.

Ćwikła, Leszek. 2015. „Instytucja urlopu wypoczynkowego”. W: Ochrona pracy w okresie międzywojennym w Polsce. Studium historyczno-prawne, red. Karol Dąbrowski, Sebastian Kwiecień, 61-91. Lublin: Wydawnictwo KUL.

Faecher, Stanisław. 1937. „Pociągi popularne w czteroleciu 1933-1936 r.” Biuletyn Komisji Studiów Ligi Popierania Turystyki 1: 19-47.

Fularski, Mieczysław. 1935. Zagadnienia ruchu turystycznego. Warszawa: Główna Księgarnia Wojskowa.

Jackowski, Antoni. 1998. „Pielgrzymki = turystyka pielgrzymkowa = turystyka religijna? Rozważania terminologiczne". Turyzm 8, z. 1: 5-20.

Jackowski, Antoni. 2003. Święta przestrzeń świata. Podstawy geografii religii. Kraków: Wydawnictwo Uniwersytetu Jagiellońskiego.

Komarnicki, Wacław. 1922. Polskie prawo polityczne (geneza i system). Warszawa: Księgarnia F. Hoesicka.

Łazarek, Marianna, Roman Łazarek. 2005. Śladami historii turystyki. Od starożytności do współczesności. Lublin: Drukarnia Akademicka.

Łysko, Marcin. 2013. „Przepisy wyznaniowe w konstytucjach II Rzeczypospolitej”. Przeglad Prawa Wyznaniowego 5: 65-82.

Makowski, Wacław. 1913. Prawo o stowarzyszeniach, zwiazkach i zgromadzeniach publicznych. Warszawa: Skład główny w księgarni G. Centnerszwera i S-ki; Drukarnia Naukowa.

Mezglewski, Artur. 2011. „Kult publiczny”. W: Prawo wyznaniowe, red. Artur Mezglewski, Henryk Misztal, Piotr Stanisz, 223-231. Warszawa 2011: Wydawnictwo C.H. Beck.

Michałek, Andrzej. 2004. Wyprawy krzyżowe. Warszawa: Bellona.

Michałowski, Kazimierz. 2003. „Analiza i perspektywy rozwoju turystyki religijnej i pielgrzymkowej w Polsce północno-wschodniej”. W: Turystyka a religia, red. Józef Bergier, Jarosław Żbikowski, 177-190. Biała Podlaska: Wydawnictwo PWSZ w Białej Podlaskiej.

Mruk, Wojciech. 1996. „Status prawny pielgrzymów. Wybrane aspekty prawne pielgrzymowania w wiekach średnich”. Peregrinus Cracoviensis 4: 113-124.

Ohler, Norbert. 2000. Życie codzienne pielgrzymów w średniowieczu. Między modlitwa a przygodą. Kraków: Wydawnictwo WAM. 
Ostrowski, Maciej. 1996. Duszpasterstwo wobec wolnego czasu człowieka. Aspekt moralno-pastoralny za szczególnym uwzględnieniem zagadnień turystyki. Kraków: Wydawnictwo Naukowe PAT.

Peiper, Leon. 1933. Komentarz do kodeksu karnego, prawa o wykroczeniach i przepisów wprowadzających wraz z niektóremi ustawami dodatkowemi i wzorami orzeczeń do prawa o wykroczeniach. Kraków: Leon Frommer.

Piekarski, Stanisław. 1927. Wyznania religijne w Polsce. Warszawa: Wydawnictwo M. Arcta.

Potocki, Andrzej. 2007. „W kierunku turystyki religijnej (z badań ruchu pielgrzymkowego na Podkarpaciu)". W: Drogi i bezdroża sportu i turystyki, red. Zbigniew Dziubiński, 217-226. Warszawa: Akademia Wychowania Fizycznego Józefa Piłsudskiego; Salezjańska Organizacja Sportowa RP.

Różycki, Paweł. 2016. Turystyka a pielgrzymowanie. Kraków: Wydawnictwo WAM.

Strzelczyk, Jerzy. 2004. Średniowieczny obraz świata. Poznań: Wydawnictwo Poznańskiego Towarzystwa Przyjaciół Nauk.

Szczepański, Jan Alfred. 1935. „Pociągi popularne”. Turysta w Polsce 3: 6.

Tunia, Anna. 2014. „Działalność turystyczno-pielgrzymkowa związków wyznaniowych jako przejaw swobody wykonywania funkcji religijnych i działania na rzecz dobra wspólnego". W: Kościoły i inne zwiąki wyznaniowe w stużbie dobru wspólnemu, red. Wacław Uruszczak, Katarzyna Krzysztofek, Maciej Mikuła, 239-252. Kraków: Wydawnictwo Uniwersytetu Jagiellońskiego.

Uruszczak, Wacław. 2018. „Średniowieczne prawo turystyczne - prawo pielgrzymów w Corpus Iuris Canonici". W: Prawne aspekty podróży i turystyki - historia i wspótczesność. Prace poświęcone pamięci Profesora Janusza Sondla, red. Piotr Cybula, 545-558. Kraków: Wydawnictwo Uniwersytetu Jagiellońskiego.

\section{LEGAL ASPECTS OF THE DEVELOPMENT OF PILGRIMAGE TOURISM IN POLAND BETWEEN 1918 AND 1939}

Abstract

In the Second Republic of Poland, an important religious, cultural and socio-economic phenomenon was - as it is today - pilgrimage tourism. The author's intention was to analyze the laws in force at that time and to answer the question whether the state legislation had a positive impact on the development of this type of tourism. The basic normative acts in this respect were the Constitution of 
March and the Constitution of April, whose provisions guaranteed, among others, the freedom of worship to citizens, and religious organizations, recognized by the state, the right to hold collective and public services. When it comes to ordinary legislation, the provisions of the 1932 Criminal Code, the 1932 Law on Assemblies and the provisions relating to time off from work (establishing holidays and introducing the institution of rest leave) were analyzed. Attention was also drawn to the draft of the "Tourism Act", which contained regulations affecting the development of pilgrimage tourism. Next, the paper focuses on the legal acts issued by the Minister of Communication, providing concessions for pilgrims travelling by train, and on the legal acts issued by other bodies, containing regulations for pilgrims going abroad or coming from abroad to Poland. After the analysis of the legal regulations, it was concluded that the actions of the state authorities, recognizing the important role of religion in the functioning of the state and society, favored the development of pilgrimage tourism. The regulations did not provide for restrictions which resulted in the practice of such tourism without restraint.

Key words: tourism; pilgrimages; pilgrimage tourism; March Constitution; Constitution of the Republic of Poland of 1921; legislation on religion; freedom of worship; freedom of conscience and religion 